\title{
Utilization GPS/QZSS Data for Determination of User's Position
}

\author{
Kamil Krasuski
}

Team of Satellite Techniques, ul. Zawiszy Czarnego 16, 08-530 Dęblin

\begin{abstract}
This paper presents studies results of standalone positioning, based on GPS/QZSS observations. For this purpose $\mathrm{C} 1$ code observations from STK2 station (IGS station in Japan) were used. Computations in RTKLIB software (RTKPOST module) were executed and SPP method was used to position estimation. In the paper two experiments were realized: firstly user's position was estimated based on GPS observations, and in second case QZSS observations were applied also. Preliminary results of positioning accuracy show that GPS/QZSS solution improve accuracy of $X$ coordinate about $0.398 \mathrm{~m}$, accuracy of $Y$ coordinate about $0.432 \mathrm{~m}$ and accuracy of $Z$ coordinate about $0.285 \mathrm{~m}$, respectively. Additionally RMS-3D error was estimated based on coordinates differences from GPS and GPS/QZSS solutions. Average value of RMS-3D term equals to $0.986 \mathrm{~m}$, with magnitude order between $0.003 \mathrm{~m}$ and $3.649 \mathrm{~m}$.
\end{abstract}

Keywords: GPS, QZSS-Zenith, SPP method, positioning accuracy

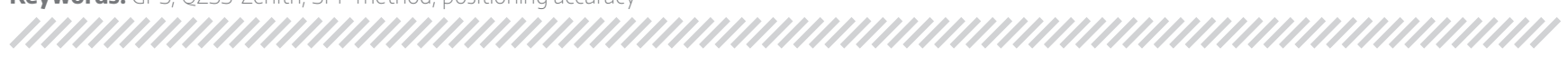

\section{Introduction}

Quasi-Zenith Satellite System (QZSS-Zenith) is a regional positioning system which was built by Satellite Positioning Research and Application Center - SPAC, foundation of Japanese Government [11]. In primary conceptions, QZSS system had assured coverage over Eastern Asia and Australia with Oceania. The MGEX campaign underlines possibility of utilization QZSS signals also in Central Europe [21]. Major principles of the system were development around to 3 functions: positioning accuracy improvement, positioning available time improvement, and transmit short information about emergency warnings, such as disaster or crisis time $[3,4,9]$. QZSS system divides into 3 components: Space Segment (SS), Ground Segment (GS) and User Segment (US). Currently (year 2014), Space Segment consist of only one satellite Michibiki, which was launched in 2010 [13, 10]. Orbital plan of Michibiki satellite is similar to number "eight" with inclination angle more than 43 degree and orbital radius about $42164 \mathrm{~km}[9,18]$. Full constellation of QZSS system will include 3 satellites, located on the geosynchronous orbit IGSO. In future plan, 4 satellites from geostationary orbit (GEO) will be added to rest constellation [16]. Ground Segment contains 4 type of stations $[5,6]$ :

Autor korespondujący:

Kamil Krasuski, kk_deblin@wp.pl

Artykuł recenzowany

nadesłany 19.02.2015 r., przyjęty do druku 20.04.2015 r.
- Master Control Station (estimation orbit parameters and clock offset, generation broadcast ephemeris, introduction orbit correction),

- Monitor Station (received and distributed QZSS observations),

- Tracking Station (upload navigation massege and monitor satellites status),

- Time Management Station (determination time transfer). Stations number of Ground Segment equal to 10 and they are located in the Japan ( 5 stations), in the USA (2 stations), in the India (1 station), in the Australia (1 station), in the Thailand (1 station) [7]. User Segment include multiplexing receivers, which can register and collect Multi-GNSS observations.

QZSS system has important influence in urban area in Japan, where signals from GPS or GLONASS satellites could be reflected from high buildings, what causes problem with positioning [2]. In article preliminary results of standalone positioning in urban region were presented. Reference data from Shintotsukawa city (Hokkaido island) were used to computations and processing of GPS/QZSS observations were implemented in RTKLIB software. Single Point Positioning (SPP) method was used for determination receiver coordinates.

\section{Mathematical Model for Position Estimation}

Basic equation to determination of user's position, based on GPS/QZSS observations, is given by [12]:

$$
\begin{aligned}
& C 1_{G P S}=\rho_{G P S}+C\left(d t r_{G P S}-d t s_{G P S}\right)+I_{G P S}+T_{G P S}+\operatorname{Re} l_{G P S}+T G D_{G P S} \\
& C 1_{Q Z S S}=\rho_{Q Z S S}+C\left(d t r_{Q Z S S}-d t s_{Q Z S S}\right)+I_{Q Z S S}+T_{G Z S S}+\operatorname{Re} l_{Q Z S S}+T G D_{Q Z S S}
\end{aligned}
$$


where:

$C 1_{G P S}, C 1_{\text {QZSS }}$ - code observations in GPS and QZSS system, $\rho_{G P S}, \rho_{\text {QZSS }}-$ geometric range between satellite (GPS/QZSS) and receiver,

$C$ - speed light,

$d t s_{G P S}, d t s_{Q Z S S}$ - satellite clock offset (GPS/QZSS),

$d t r_{G P S}, d t r_{Q Z S S}$ - receiver clock offset (GPS/QZSS),

$I_{G P S}, I_{Q Z S S}$ - ionosphere delay in GPS and QZSS system,

$T_{G P S}^{G P S}, T_{\text {OZSS }}$ - troposphere delay in GPS and QZSS system,

$\operatorname{Re} l_{G P S}, \operatorname{Re} l_{Q Z S S}-$ relativistic effect in GPS and QZSS system,

$T G D_{G P S}, T G D_{Q Z S S}$ - transmitter group delay in GPS and QZSS system $[7,15]$.

Equation (1) presents Single Point Positioning (SPP) method and it's very popular solution, especially in standalone positioning and navigation. The left side of equation (1) include raw observations from RINEX file and they are expressed in meter unit. Whereas the right side, measurements models and unknown parameters are described. Usually measurements models represent group of systematic errors such as: satellite clock bias, ionosphere and troposphere delay, relativistic effect and instrumental biases. Rest terms in equation (1) are called unknown parameters and contain correction to geocentric coordinates XYZ (3 parameters) and receiver clock bias (one parameter). In case of hybrid data (see equation 1$)$, number of estimated parameters will be 5 (additionally unknown parameter is a receiver clock in QZSS system).

Least square method is applied to solve the equation (1) and reads as follows [17]:

$$
A \cdot \delta x+l=v
$$

where:

$A$ - matrix of coefficients; matrix with dimension $(n, k)$,

$n$ - number of observations,

$k$ - number of unknown parameters,

$\delta x$ - vector with unknown parameters,

$l$ - vector of observations,

$v$ - vector of residuals.

Vector $\delta x$ with unknown parameters is estimated from normal equations, as below [14]:

$$
\delta x=\left(A^{T} \cdot \mathrm{A}\right)^{-1} \cdot A^{T} \cdot l
$$

Mean errors for unknown parameters are solved based on equation (4) [1]:

$$
m x=m 0 \cdot \sqrt{\left(A^{T} \cdot A\right)^{-1}}
$$

where:

$m 0$ - standard error of unit weight,

$m 0=\sqrt{\frac{v v}{n-k}}$.

Equations (3) and (4) should be applied for each measurements epoch from RINEX file in iterative scheme. If unknown parameters from equation (3) will be estimated then user's position must also be corrected. The $m x$ term in equation (4) expresses accuracy for unknown parameters.

\section{Experiments and Results}

Analysis was based on 24 hours (with interval 30 seconds) GPS/QZSS data from STK2 station in RINEX format 3.00. STK2 reference station (see Fig. 1) is located in Shintotsukawa (Hokkaido island) in north Japan (coordinate: $43.52 \mathrm{~N}$, $141.84 \mathrm{E})$. Station has dual frequency receiver TRIMBLE NETR9 (version 4.61), which makes enable to tracking GPS, GLONASS and QZSS satellites. Receiver TRIMBLE NETR9 is

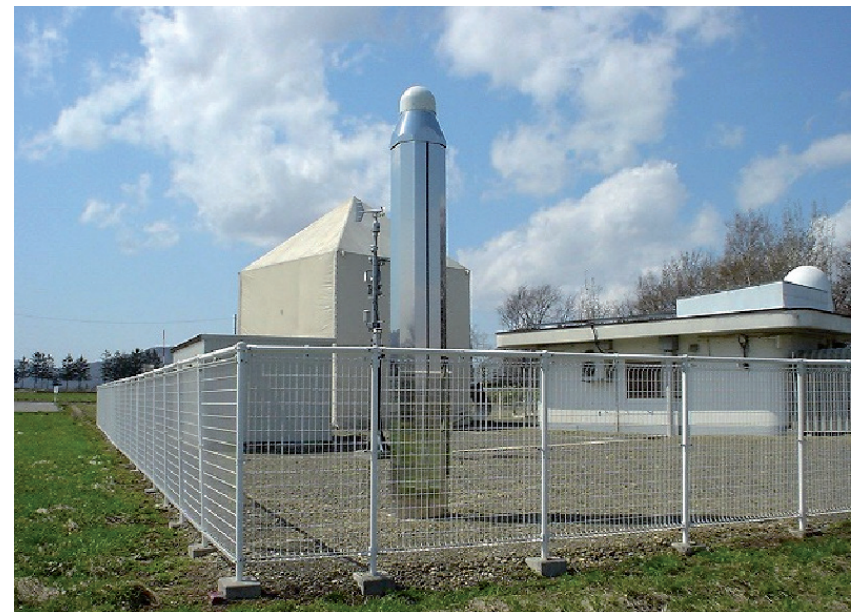

Fig. 1. The STK2 site in Japan [20]

Rys. 1. Stacja STK2 w Japonii [20]

a part of IGS service, and more information about station are available on the website [20]. RINEX data and broadcast ephemeris (GPS and QZSS) to calculations, for day 4 October 2014, were downloaded from BKG server [19]. RTKPOST module in RTKLIB software [22] was utilized in computations processing.

The main options in code source of RTKPOST module was configured and applied, as below:

- RINEX file type: RINEX 3.00,

- source of GPS/QZSS ephemeris data: Broadcast Ephemeris,

- method of satellite position determination: based on Broadcast Ephemeris,

- Earth rotation correction: applied,

- source of GPS/QZSS satellite clock data: Broadcast Ephemeris,

- method of satellite clock determination: interpolation using 2-degree polynomial,

- ionosphere delay: Klobuchar model,

- source of coefficients in Klobuchar model: GPS/QZSS navigation message,

- troposphere delay: Saastamoinen model,

- instrumental biases: TGD applied (based on Broadcast Ephemeris),

- satellite phase center offset/variation: not applied,

- receiver phase center offset/variation: not applied,

- multipath effect: not applied,

- positioning mode: single

- processing mode: static,

- basic observations: C1 code,

- mathematical model of user's position determination: least square estimation,

- weight matrix of measurements: not implemented for SPP method in RTKLIB,

- cut off elevation: $10^{\circ}$,

- reference frame: WGS-84,

- number of unknown parameters: $k=4$, or $k=5$,

- number of observations: $n>4$,

- approximately coordinates of user's position: based on RINEX file,

- output solution of coordinates: XYZ in geocentric frame,

- receiver clock: estimated parameter.

In submitted paper two experiments were realized. In the first test, user's position was estimated based on only GPS observations and in second case, receiver coordinates were calculated using GPS/QZSS data. Mean errors from both solutions were compared and visualized into Fig. 2 and 4. Measurement epochs (about 1000) without QZSS observations were removed from comparison processing. Figure 2 presents results of positioning accuracy for $\mathrm{X}$ coordinate. 


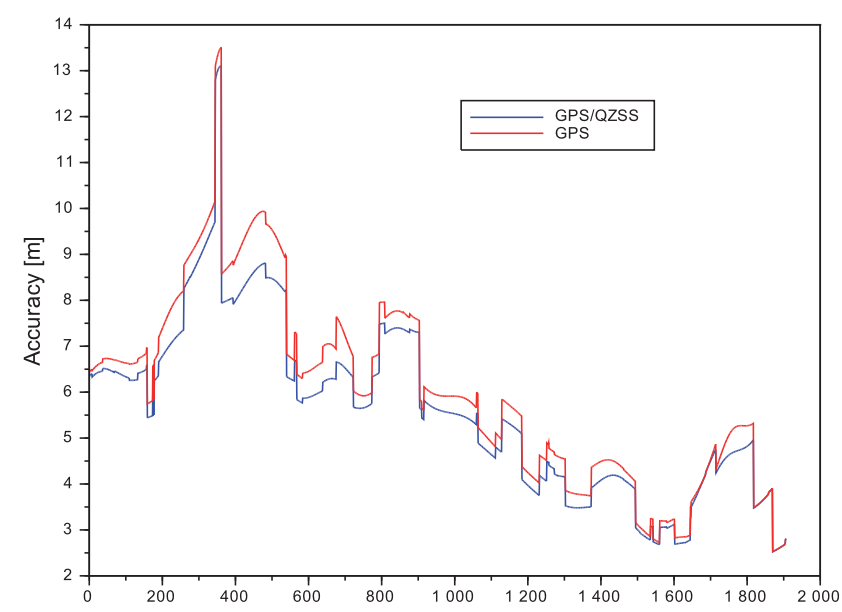

Fig. 2. Mean errors of $X$ coordinate

Rys. 2. Błędy średnie współrzędnej $X$

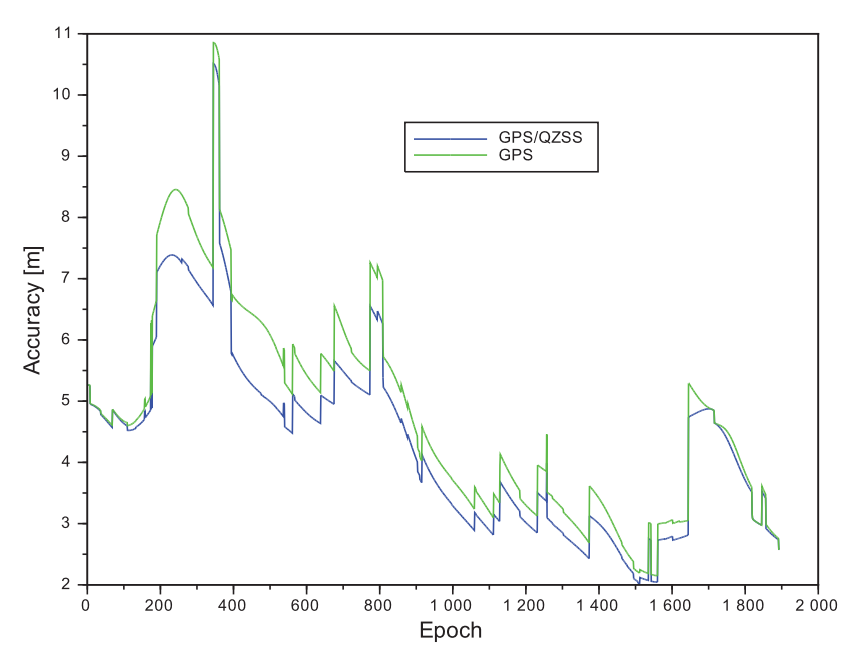

Fig. 3. Mean errors of $Y$ coordinate

Rys. 3. Błędy średnie współrzędnej $Y$

Magnitude of mean errors for GPS solution are between $2.531 \mathrm{~m}$ and $13.510 \mathrm{~m}$, for GPS/QZSS solution are between $2.523 \mathrm{~m}$ and $13.103 \mathrm{~m}$, respectively. Generally average value of mean errors for each solutions equals to $6.019 \mathrm{~m}$ and 5.621 $\mathrm{m}$, respectively. Mean difference of accuracy between GPS and GPS/QZSS solution for X coordinate amounts to 0.398 $\mathrm{m}$ with standard deviation $0.264 \mathrm{~m}$. Based on Fig. 2, mean errors of X component are lower for GPS/QZSS solution than GPS solution.

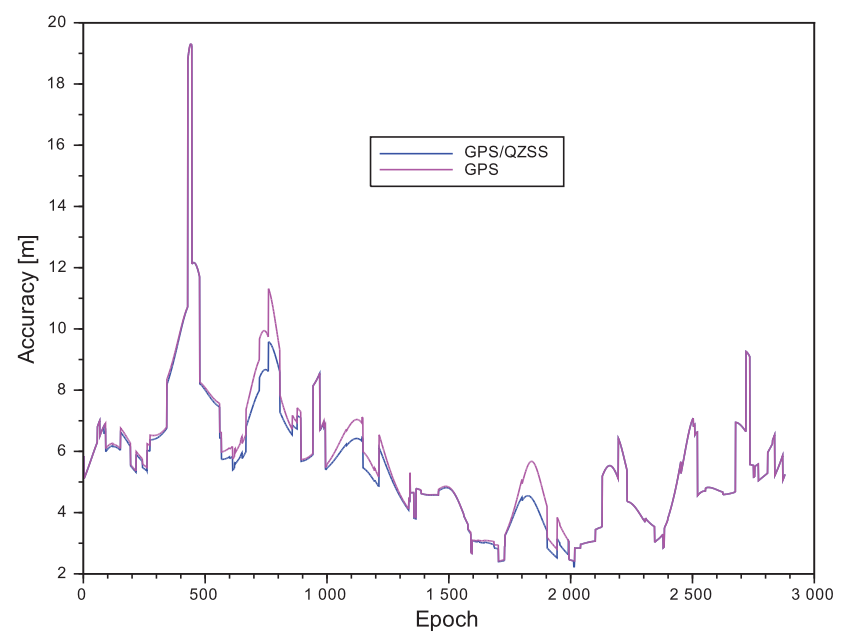

Fig. 4. Mean errors of $Z$ coordinate

Rys. 4. Błędy średnie współrzędnej Z
Table 1. Results of correlation coefficients for mean errors $M_{x}, M_{y}$, and $M$ Tabela 1. Wyniki współczynników korelacji dla błędów średnich $M_{x}, M_{y}$, oraz $M_{z}$

\begin{tabular}{|c|c|}
\hline Index of parameter & Average value \\
\hline$q x$ & 0.938 \\
\hline$q y$ & 0.913 \\
\hline$q z$ & 0.953 \\
\hline
\end{tabular}

Figure 3 shows positioning accuracy results for $\mathrm{Y}$ coordinate. Based on Fig. 3, mean errors of Y term are similar for GPS/ QZSS and GPS solutions. Maximum and minimum values of mean errors for both solutions are about $2.014 \mathrm{~m}$ and 10.856 $\mathrm{m}$, adequately. Average value of accuracy for both solutions equals to $4.769 \mathrm{~m}$ and $4.337 \mathrm{~m}$, respectively. Mean difference of accuracy between GPS and GPS/QZSS solution for Y coordinate amounts to $0.432 \mathrm{~m}$ with standard deviation $0.303 \mathrm{~m}$. Influence of QZSS observations for determination accuracy of $\mathrm{Y}$ coordinate is on the same accuracy level like $\mathrm{X}$ coordinate.

Figure 4 presents positioning accuracy results for Z coordinate. Magnitude order of accuracy for GPS and GPS/QZSS solutions is between $2.215 \mathrm{~m}$ and $19.310 \mathrm{~m}$. Average value of accuracy for both solutions is about $6.131 \mathrm{~m}$ and $5.845 \mathrm{~m}$, respectively. Difference of accuracy between GPS and GPS/ QZSS solution for Z coordinate amounts to $0.285 \mathrm{~m}$ with standard deviation $0.349 \mathrm{~m}$.

Relation between mean errors from both solutions can be expressed, as below:

$$
\left\{\begin{array}{l}
q x=\frac{M x_{G P S / Q Z S S}}{M x_{G P S}} \\
q y=\frac{M y_{G P S} / Q Z S S}{M y_{G P S}} \\
q z=\frac{M z_{G P S / Q Z S S}}{M z_{G P S}}
\end{array}\right.
$$

where:

$q x, q y, q z$ - correlation coefficients between mean errors for GPS and GPS/QZSS solutions,

$M x_{G P S}, M x_{G P S / Q Z S S}$ - mean errors of $\mathrm{X}$ coordinates for both solutions (see Fig. 2),

$M y_{G P S}, M y_{G P S / Q Z S S}$ - mean errors of Y coordinates for both solutions (see Fig. 3),

$M z_{G P S}, M z_{G P S / Q Z S S}$ - mean errors of $\mathrm{Z}$ coordinates for both solutions (see Fig. 4).

Table 1 presents results of correlations coefficients between mean errors for GPS and GPS/QZSS solutions. The $q x$ term equals to 0.938 , that is the reason that solution GPS/QZSS improved accuracy of X coordinate more than $6 \%$. In case of $q y$ coefficient, GPS/QZSS solution decreased mean errors of Y coordinate close to $9 \%$. Influence of GPS/QZSS solution on the $\mathrm{Z}$ coordinate can reduced mean errors only to $5 \%$ (see $q z$ term). In connection with it, GPS/QZSS solution has got a little impact for accuracy improvement of $\mathrm{Z}$ coordinate. Additionally, mean errors $M z$ are large in comparison to mean errors $M x$ and $M y$.

The RMS-3D factor was also obtained in positioning accuracy analysis. The equation of RMS-3D index can be described, as follows: 


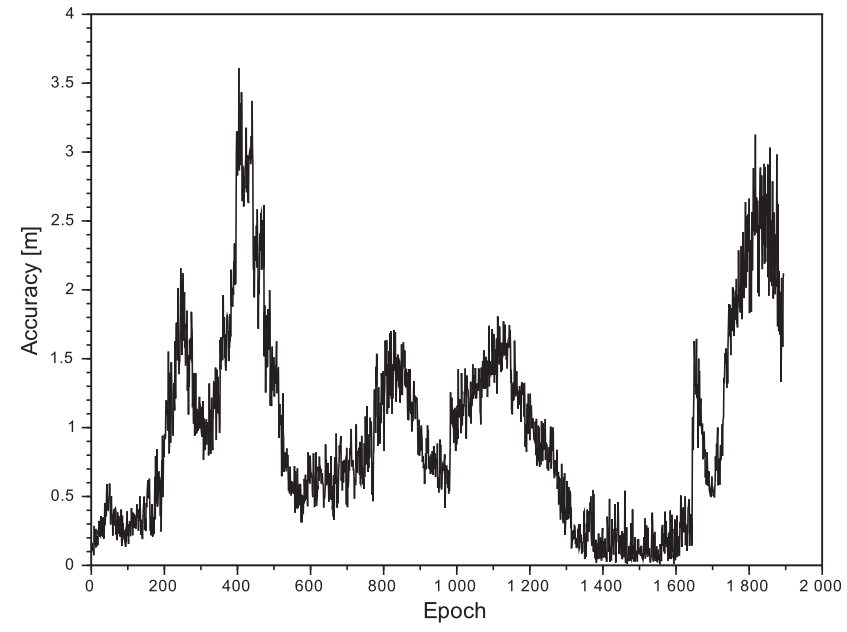

Fig. 5. Results of RMS-3D error

Rys. 5. Wyniki błędu RMS-3D

$$
\mathrm{RMS}-3 \mathrm{D}=\sqrt{\Delta X^{2}+\Delta Y^{2}+\Delta Z^{2}}
$$

where:

$\Delta X=X_{G P S / Q Z S S}-X_{G P S}-$ difference between $\mathrm{X}$ coordinates from GPS and GPS/QZSS solutions,

$\Delta Y=Y_{G P S / Q Z S S}-Y_{G P S}-$ difference between $\mathrm{Y}$ coordinates from GPS and GPS/QZSS solutions,

$\Delta Z=Z_{G P S / Q Z S S}-Z_{G P S}-$ difference between $\mathrm{Z}$ coordinates from GPS and GPS/QZSS solutions.

Figure 5 shows RMS-3D results based on XYZ coordinates from GPS and GPS/QZSS solutions.

Based on Fig. 5, average value of RMS-3D error amounts to $0.986 \mathrm{~m}$, with magnitude between $0.003 \mathrm{~m}$ and $3.649 \mathrm{~m}$. More than $57 \%$ results of RMS-3D errors are less than $1 \mathrm{~m}$, but about $90 \%$ results of RMS-3D errors are less than $2 \mathrm{~m}$. Trend of RMS-3D errors is very irregularity and includes 2 anomalies: between epochs 400-500, and 1700-1800. In these cases, mean errors of XYZ coordinates (see Fig. 2, 3 and 4) are changed diametrically and they are started to raise up. This situation is very negative, especially for coordinates values, because RMS-3D can reach up more than $3.5 \mathrm{~m}$. Similar phenomena can be seeing in behavior of mean errors of each coordinates into Fig. 2, 3 and 4.

\section{Conclusions}

Results of standalone positioning using GPS/QZSS data were presented in article. Example code observations were taken from RINEX 3.00 file from STK2 station in Japan. Computations were executed in RTKLIB software (RTKPOST module) using SPP method. The receiver coordinates were solved twice: in first test only GPS observations were used, but in second case QZSS data were also applied. Preliminary results show that GPS/QZSS solution improve accuracy of X coordinate about $0.398 \mathrm{~m}$, accuracy of $\mathrm{Y}$ coordinate about $0.432 \mathrm{~m}$ and accuracy of $\mathrm{Z}$ coordinate about $0.285 \mathrm{~m}$, respectively. Moreover correlation coefficients were obtained for mean errors of XYZ coordinates from each solutions. Generally GPS/QZSS solution increased accuracy of each coordinates between $5 \%$ to $9 \%$. The RMS-3D errors between XYZ coordinates from GPS and GPS/QZSS solutions were estimated also. Average bias of RMS-3D parameters is about $0.986 \mathrm{~m}$, with magnitude order between $0.003 \mathrm{~m}$ and $3.649 \mathrm{~m}$.

\section{Acknowledgements}

The author would like to acknowledge BKG Service for making available RINEX data and Mr. Takasu for making available RTKLIB software.

\section{Bibliography}

1. Angrisano A., GNSS/INS Integration Methods, Dissertation Thesis, Napoli 2010.

2. Angrisano A., Pacifico A., Vultaggio M., Augmentation satellites constellations, a simulation on EGNOS and QZSS for Europe coverage, ENC 2008.

3. Aoki M., QZSS The Japanese Quasi-Zenith Satellite System: Program Updates and Current status, $15^{\text {th }}$ International Committee on GNSS, Torino 2010.

4. Fujiwara S., QZSS and MSAS The Quasi-Zenith Satellite System and The Multi-functional Transport Satellite Satellite-based Augmentation System, ICG-6, Tokyo 2011.

5. JAXA, Impact of SLR tracking on QZSS, ILRS Workshop, Metsovo 2009.

6. JAXA, Interface Specification for QZSS (IS-QZSS), version 1.5, 2013.

7. JAXA, Interface Specification for QZSS (IS-QZSS), version 1.6, 2014.

8. Kogure S., QZSS in Asia and Oceania Region, $15^{\text {th }}$ Asia Pacific Region Space Agency Forum, Hanoi 2008.

9. Kogure S., The status of Quasi-Zenith Satellite System (QZSS) technical demonstration, United Nations Economic and Social Commission for Asia and the Pacific(UN ESCAP), Workshop on Use of Multi - Global Navigation Satellite Systems for Sustainable Development, Bangkok 2012.

10. Li Y., Rizos C., Evaluation of positioning accuracy with QZSS enhanced global navigation satellite systems, 2012, available at: [www.gmat.unsw.edu.au/snap/publications/ liy\&rizos2012a.pdf].

11. Matsuoka S., Service status of QZSS, The Asia Pacific Regional Space Agency Forum, Communication Satellite Application WG, 2008.

12. RTKLIB ver. 2.4.2.

13. Sakai T., Fukushima S., Ito K., QZSS L1-SAIF Initial Experiment Results, ION ITM, San Diego 2011.

14. Sanz Subirana J., Juan Zornoza J. M., Hernández-Pajares M., GNSS DATA PROCESSING, Volume I: Fundamentals and Algorithms, ESA, 2013.

15. Spits J., Total Electron Content reconstruction using triple frequency GNSS signals, Dissertation thesis, Universitè de Liège, Belgium, 2011.

16. Takasu T., Ebinuma T., Yasuda A., Effect of Quasi Zenith Satellite (QZS) on GPS Positioning, 2009, retrieved from [http://gpspp.sakura.ne.jp/paper2005/isgps_2009_ qzs_8_.pdf].

17. Takasu T., RTKLIB ver. 2.4.2 Manual, 2013.

18. Yoshitomi S., GNSS Augmentation using Quasi-Zenith Satellite System (QZSS) and its benefits for satellite navigation applications, $10^{\text {th }}$ Meeting of the APEC Global Navigation Satellite system (GNSS), Implementation Team (GIT/10), Philippines, 2006.

19. [http://igs.bkg.bund.de/file/rinexsearch/], current on 2015.

20. [http://igscb.jpl.nasa.gov/network/site/stk2.html], current on 2015.

21. [www.igs.org/mgex], current on 2015.

22. [www.rtklib.com], current on 2015. 


\title{
Wykorzystanie obserwacji GPS/OZSS do wyznaczania pozycii użytkownika
}

Streszczenie: Artykuł przedstawia wyniki badań dotyczących pozycjonowania absolutnego z wykorzystaniem obserwacji GPS/QZSS. W ramach przeprowadzonych badań zostały wykorzystane obserwacje kodowe C1 ze stacji STK2 (stacja IGS na terenie Japonii). Obliczenia zostały zrealizowane w programie RTKLIB (w module RTKPOST), a do wyznaczenia pozycji została zaproponowana metoda pozycjonowania absolutnego (SPP). W eksperymencie badawczym wykonano 2 testy: w pierwszym pozycja użytkownika została wyznaczona na podstawie obserwacji GPS, a w drugim na podstawie obserwacji GPS/QZSS. Wstępne wyniki dokładności pozycjonowania są obiecujące, na podstawie obserwacji GPS/QZSS. Rozwiązanie GPS/QZSS poprawiło odpowiednio błędy średnie współrzędnej X o 0,398 m, współrzędnej Y o 0,432 m, zaś współrzędnej Z o 0,285 m. Dodatkowo błąd RMS-3D został wyznaczony na podstawie różnicy współrzędnych z rozwiązania GPS oraz GPS/QZSS. Średnia wartość tego parametru wyniosła 0,986 m, dla przedziału wartości od $0,003 \mathrm{~m}$ do $3,649 \mathrm{~m}$.

\section{Kamil Krasuski, M.Sc. Eng.}

\author{
kk_deblin@wp.p
}

Alumnus of Military Technical Academy in Warsaw. Author of SciTEC Toolbox software for determination ionosphere parameters. Author of Local Ionosphere Monitoring System in District Ryki [http://ztsdeblin.16mb.com/index.html]. Area of interests: navigation, geodesy, geophysics. Since 2014 - Team of Satellites Techniques.

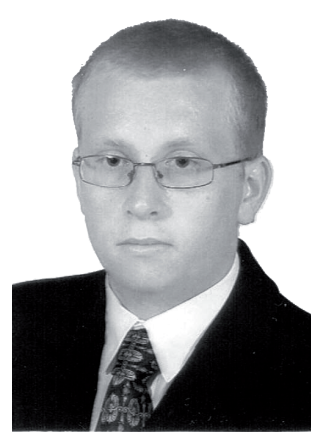

